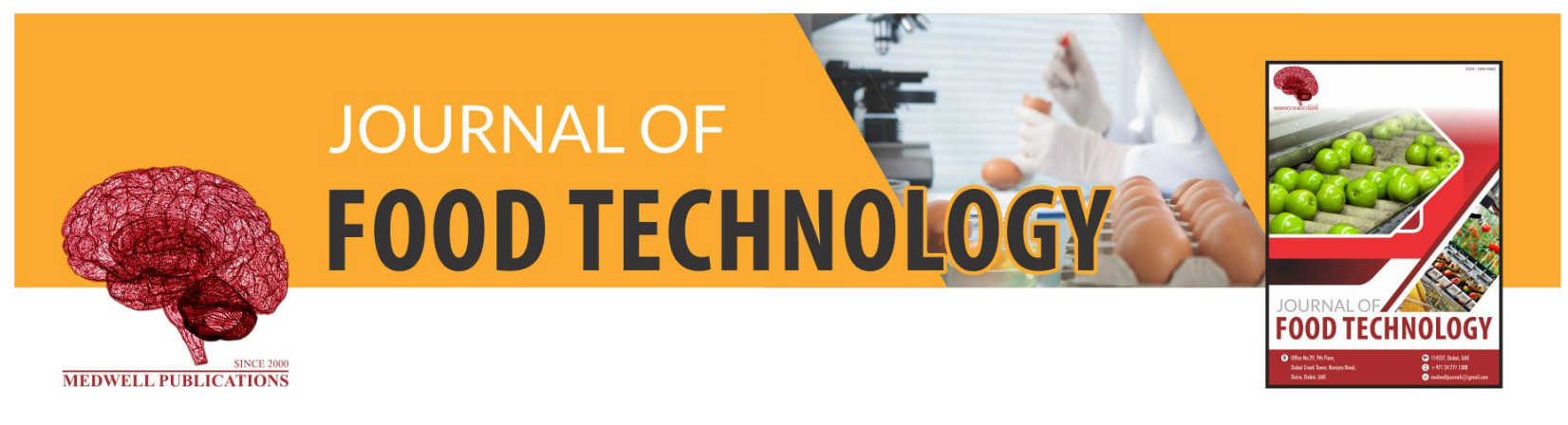

\title{
Sorption Isotherm Characteristics of Water Yam (Dioscorea alata) Flour
}

\author{
A.F. Okeleye, T.A. Morakinyo and C.T. Akanbi \\ Department of Food Science and Technology, Obafemi Awolowo University, Ile-Ife, Nigeria
}

Key words: Water yam flour, sorption isotherm, hysteresis, isosteric heat of sorption, adequate

Corresponding Author:

A.F. Okeleye

Department of Food Science and Technology, Obafemi Awolowo University, Ile-Ife, Nigeria

Page No.: 46-52

Volume: 17, Issue 4, 2019

ISSN: $1684-8462$

Journal of Food Technology

Copy Right: Medwell Publications
Abstract: The study assessed the sorption isotherm characteristics of water yam flour. This was in the view to predict the stability of the water yam flour under different humid conditions. The sorption isotherm of water yam flour obtained from blanched and un-blanched water yam cubes was determined by the static gravimetric method using sulphuric acid solution at 25,35 and $45^{\circ} \mathrm{C}$ in the water activity range of 0.09-0.96.The un-blanched samples had higher equilibrium moisture content values than the blanched samples at the same water activity level and same temperature for both the adsorption and desorption processes. They also exhibited hysteresis loop over considerable levels of water activity. GAB model gave the overall best description to the sorption characteristics of the water yam flour out of the five sorption models fitted to the experimental data. The isosteric heat of adsorption and desorption decreases with increasing temperature. The study would be useful in the design and selection of adequate packaging materials and establishment of preferred humidity level during storage.

\section{INTRODUCTION}

Moisture content control during food processing is an ancient method of food preservation (Al-Muhtaseb et al., 2002). The moisture content present in a food product is highly related to its water activity and this relationship is described by sorption isotherm (Oluwamukomi et al., 2008). The knowledge of the sorption isotherms of food materials is highly important in food processing for predicting food quality and shelf stability, design of drying equipment and packaging materials and also for monitoring the change in moisture content of the food that is likely to occur during storage (Andrade et al., 2011). Multi plevarieties of water yam (Dioscorea alata) have been introduced to develop different food products in Africa (Mignouna and Dansi, 2003). Water yam is one of the most widely distributed yam species globally (Mignouna et al., 2003) and the world's most popular white yam after the $D$. rotundata/D. cayenensis. The tuber has high moisture content hence the name "water yam". According to Opara (1999), water yam has a water content of $65-76 \%$ per 100 gedible tuber portion. The high moisture content of the yam tubers makes it highly perishable thereby prompting the need to process it into flour as an intermediate product in order to enhance its shelf stability and utilization (Harijono et al., 2013). Water yam flour is underutilized due to its quality when compared with other yam flour like white yam flour; this thereby affects its acceptability worldwide.

The effects of water activity $\left(a_{w}\right)$ in food contributes to the loss of quality in most dried foods when stored, this has greatly influenced the biochemical reactions and 
stability of the dried food products (Akanbi et al., 2006). Researches have been done on the sorption isotherm of White yam, Chinese yam, Aerial yam but not much research has been reported on the sorption isotherm of water yam. Owo et al. (2017) reported the adsorption isotherm of water yam, however, no documented information has been given on desorption isotherm of water yam. Therefore, understanding the moisture sorption characteristics of water yam flour in order to design its required packaging materials and to predict its shelf stability is important. Therefore, the aim of this research was to assess the sorption characteristics of water yam flour over specific range of water activities commonly experienced in both tropical and subtropical regions.

\section{MATERIALS AND METHODS}

Sample preparation: The water yam tubers used for this research were obtained from Obafemi Awolowo University Research Farm, Ile-Ife, Osun state. The yam tubers were washed, hand-peeled and cut into circular slices of radius $2 \mathrm{~cm}$ and thickness of $0.8 \mathrm{~cm}$. The slices $(100 \mathrm{~g})$ were blanched using hot water at $90^{\circ} \mathrm{C}$ for $1 \mathrm{~min}$ and drained. The purpose of blanching was to deactivate enzyme activities and prevent browning reaction (Satimehin, 2017). Another $100 \mathrm{~g}$ of the slices was prepared as un-blanched sample. The yam slices (blanched and un-blanched) were dried in a hot air oven at $50^{\circ} \mathrm{C}$. The dried blanched and un-blanched samples were then milled using hammer mill and kept in an air tight bag prior to analysis (Babajide et al., 2007).

Determination of adsorption isotherm: The static gravimetric method was applied in which $1 \mathrm{~g}$ of the flour samples wasplaced over sulphuric acid solutions in the range of $0.1-1.0(10-65 \% \mathrm{v} / \mathrm{v})$ in a desiccator and kept in an incubator at temperatures 25,35 and $45^{\circ} \mathrm{C}$. Sulphuric acid has been used in sorption isotherm studies by other researchers (Peng et al., 2007; Goula et al., 2008; Oyeladeet al., 2008). The samples were weighed daily in a weighing balance until an equilibrium value was attained when three consecutive values remained constant $( \pm 0.001 \mathrm{~g})$. The dry matter weight was obtained by drying the equilibrated samples in a hot air oven dryer at $70^{\circ} \mathrm{C}$ in order to evaluate the equilibrium moisture content (Akanbi et al., 2006). The average equilibrium moisture content of three replicates was calculated on dry basis ( $\mathrm{g} \mathrm{H}_{2} \mathrm{O} / \mathrm{g}$ solid).

Determination of desorption isotherm: This involved the step-wise transfer of equilibrated samples after adsorption at the highest water activity (1.0) to the range of lower water activity $\left(\mathrm{a}_{\mathrm{w}}\right)$ points of 0.8-0.1. The desiccator containing the samples was then placed in an incubator until equilibrium was attained when at least three consecutive weight measurements remained constant. The dry matter weight was obtained by drying the equilibrated samples in a hot air oven dryer at $70^{\circ} \mathrm{C}$ in order to evaluate the equilibrium moisture content (Akanbi et al., 2006). The average equilibrium moisture content of three replicates was calculated on dry basis ( $\mathrm{g} \mathrm{H}_{2} \mathrm{O} / \mathrm{g}$ solid).

Modelling equations of sorption isotherm: Five isotherm model equations as shown in Table 1 were fitted with the experimented equilibrium moisture content and water activity data.

Statistical analysis: The suitability of the models (sorption models) was determined using excel solver tool and regression data analysis by comparing three evaluation indicators for each of the models. These indicators are the Residual Sums of Squares (RSS), the sum of the Square Error (SEE) and the co-efficient of determination $\left(\mathrm{R}^{2}\right)$, each as an index of variability between the experimental and predicted data as presented in Eq. 1-3 (Akanbi et al., 2006; Oyelade et al., 2008):

$$
\begin{gathered}
\mathrm{RSS}=\sum_{\mathrm{i}=1}^{\mathrm{n}}\left(\mathrm{M}_{\text {calculated }}-\mathrm{M}_{\text {predicted }}\right) \\
\mathrm{SEE}=\sqrt{\frac{\sum_{\mathrm{i}=1}^{\mathrm{n}}\left(\mathrm{M}_{\text {calculated }}-\mathrm{M}_{\text {predicted }}\right)^{2}}{\mathrm{df}}} \\
\mathrm{R}^{2}=\left(1-\frac{\mathrm{RSS}}{\mathrm{TSS}}\right)
\end{gathered}
$$

Where:

$\mathrm{M}_{\text {calculated }}$ : Equilibrium Moisture Content (EMC) by experiment, $\%$ wet basis

$\mathrm{M}_{\text {predicted }}$ : Predicted EMC due to models (\%) wet basis

RSS : Residual Sum of Squares

TSS : Total Sum of Squares

df : Total degree of freedom

Isostericheat of sorption: The heat of absorption and desorption was calculated from the experimental data using the Clausius-Clapeyron equation (Tsami et al., 1990; Akanbi et al., 2006) as presented in Eq. 9 and 10:

Table 1: Mathematical model equations of sorption isotherm

\begin{tabular}{ll}
\hline Models & Model equation \\
$\begin{array}{l}\text { GAB (Guggenheim, } \\
\text { Anderson and de Boer) } \\
\text { equation }\end{array}$ & $\mathrm{X}=\frac{\mathrm{X}_{\mathrm{m}} \cdot \mathrm{A} \cdot \mathrm{B} \cdot \mathrm{a}_{\mathrm{w}}}{\left(1-\mathrm{C} \cdot \mathrm{a}_{\mathrm{w}}\right) \cdot(1+(\mathrm{B}-1)) \cdot\left(\mathrm{C} \cdot \mathrm{a}_{\mathrm{w}}\right)}$ \\
Oswin equation & $\mathrm{M}=\mathrm{A}\left(\frac{\mathrm{a}_{\mathrm{w}}}{1-\mathrm{a}_{\mathrm{w}}}\right)^{\mathrm{B}}$ \\
$\begin{array}{l}\text { Peleg equation } \\
\text { Smith equation }\end{array}$ & $\mathrm{M}=\mathrm{A}^{\mathrm{B}} \mathrm{a}_{\mathrm{w}}+\mathrm{C}^{\mathrm{D} \mathrm{a}_{\mathrm{w}}}$ \\
Henderson equation & $\mathrm{M}=\mathrm{A}+\mathrm{BIn}\left(1-\mathrm{a}_{\mathrm{w}}\right)$ \\
\hline
\end{tabular}

$\overline{\mathrm{M}=\text { equilibrium moisture content (\%, dry basis); } \mathrm{A}, \mathrm{B}, \mathrm{C}, \mathrm{D}=\text { unknown }}$ values to be estimated 


$$
\begin{aligned}
& \frac{\mathrm{dLna}_{\mathrm{w}}}{\mathrm{d} \ln \frac{1}{\mathrm{~T}}}=\frac{\mathrm{dH}_{\mathrm{c}}}{\mathrm{R}} \\
& \mathrm{Q}_{\mathrm{st}}=\mathrm{H}_{\mathrm{c}}+\mathrm{H}_{\mathrm{v}}
\end{aligned}
$$

Where:

$\mathrm{Q}_{\mathrm{st}}$ : The isosteric heat of sorption $\left(\mathrm{kJ} \mathrm{moL}^{-1}\right)$

$\mathrm{H}_{\mathrm{c}}$ : The Heat of interaction of water vapour with solid substance

$\mathrm{H}_{\mathrm{v}}$ : The Heat of condensation of pure water at $35^{\circ} \mathrm{C}$ (the average temperature of 25,35 and $45^{\circ} \mathrm{C}$ )

$\mathrm{R}$ : The gas constant $\left(\mathrm{kJ} \mathrm{K} \mathrm{moL}^{-1}\right)$

$\mathrm{T}$ : The absolute temperature $(\mathrm{K})$ at the corresponding $\mathrm{a}_{\mathrm{w}}$ level

\section{RESULTS AND DISCUSSION}

The experimental results for the Equilibrium Moisture Content (EMC) of the blanched and un-blanched water yam flour samples at seven different water activity levels for temperatures 25,35 and $45^{\circ} \mathrm{C}$ are presented in Fig. 1 and 2 for both the adsorption and desorption processes. The isotherm curves followed a sigmoidal shape of Type II according to the Brunauer, Emmet and Teller classification as reported by Andraade et al. (2011). Similar shape was reported by Oyelade et al. (2008), Kaymak-Eretekin and Gedik (2004) and Owo et al. (2017) in their studies on white yam, potato and water yam flour, respectively.

From Fig. 1 and 2, the Equilibrium Moisture Content (EMC) increased with increasing water activity at constant temperature and decreased with increase in temperature at constant water activity. This has been attributed to the hydroscopic nature of the yam flour in which more moisture is absorbed at lower temperature than at higher temperatures (Owo et al., 2017). According to Goula et al. (2008) at increased temperatures water molecules get activated to higher energy levels and break away from the water-binding sites of the flour, thereby decreasing the equilibrium moisture content.

It was also observed that the un-blanched samples had higher EMC values than the blanched samples at the same water activity level and same temperature for both the adsorption and desorption processes. This could be due to the leaching of the starch content of the yam tuber which occurred during the blanching process. The moisture sorption process is higher in foods with higher starch content (Raj et al., 2002; Oyelade et al., 2014). Similar result was observed by Onayemi and Oluwamukomi in their study on the moisture equilibra of cassava and yam products. Also, the isotherms of different temperatures for the blanched sample overlap or crossed each other at a water activity

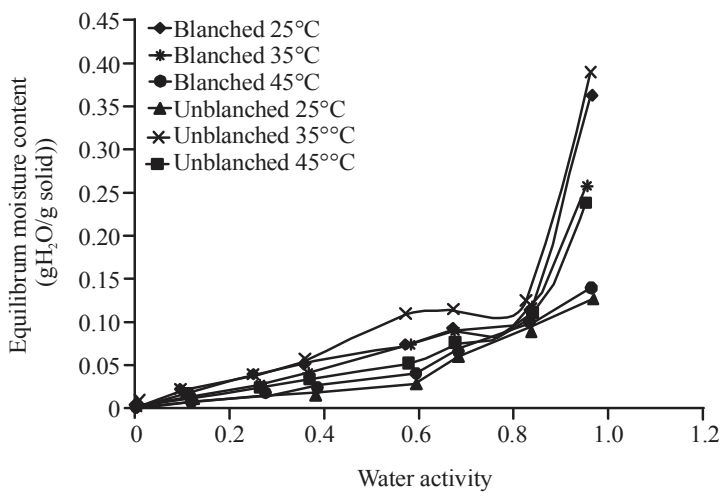

Fig. 1: Adsorption isotherm of blanched water yam flour at three different temperatures

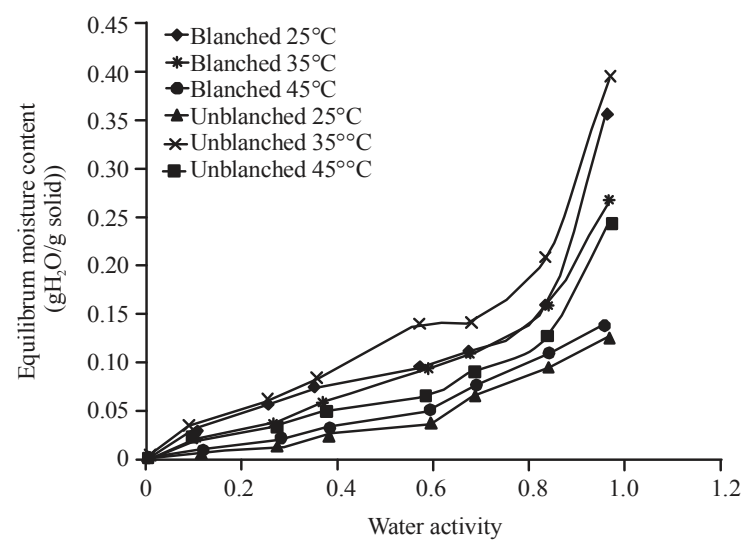

Fig. 2: Adsorption isotherm of un-blanched water yam flour at three different temperature

level $>0.8$. Gogtus et al. (1998) attributed the overlap to microbial growth and/or dissolution of sugars or crystalline substances.

Moisture sorption hysteresis loop: The adsorption and desorption curves of both the blanched and un-blanched flour samples at the three temperatures $\left(25,35\right.$ and $\left.45^{\circ} \mathrm{C}\right)$ formed a loop which exhibited the phenomenon of hysteresis as shown in Fig. 3 and 4. From the hysteresis loop obtained, it was observed that the adsorption isotherm curves were below the desorption curve at the same water activity level for both the blanched and un-blanched flour samples as shown in Fig. 3 and 4. During desorption, some solutes remain supersaturated below their crystallization water activity thereby causing water retention as water activity at minimum value (Barbosa-Canovas et al., 2008). The hysteresis loop occurred throughout the entire range of water activities used. The maximum hysteresis for all samples (blanched and un-blanched) was obtained at water activities above 0.7 which is the multilayer region and the least hysteresis was obtained at water activities below 0.3 


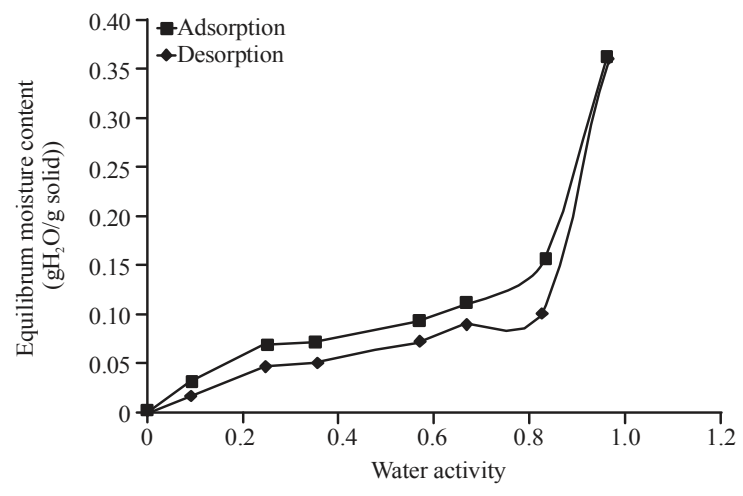

Fig. 3: Sorption hysteresis of blanched water yam flour samples at $25^{\circ} \mathrm{C}$

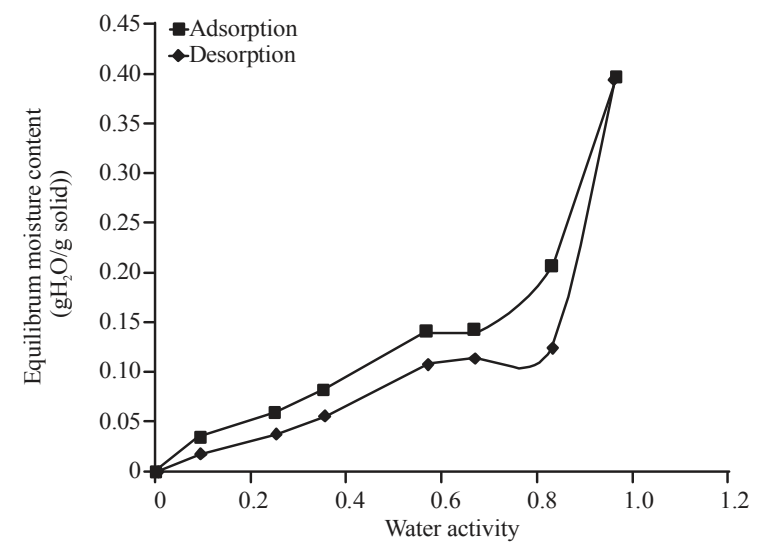

Fig. 4: Sorption hysteresis of un-blanched water yam flour samples at $25^{\circ} \mathrm{C}$

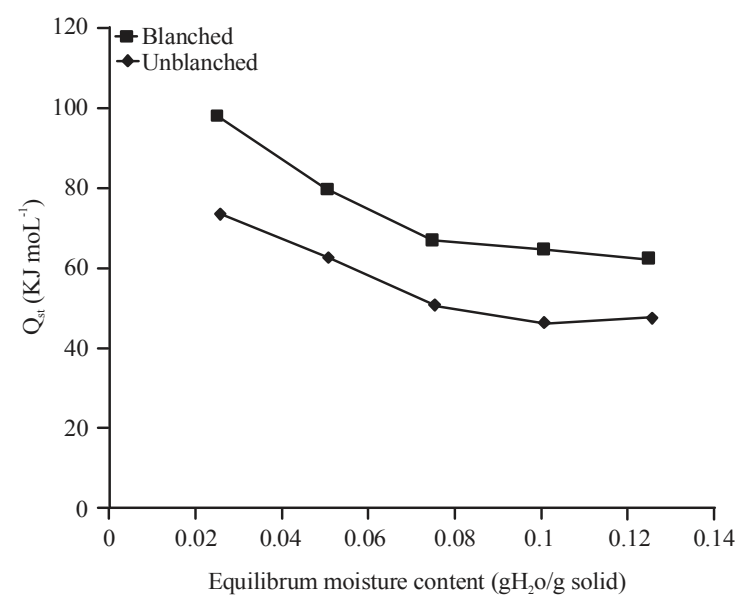

Fig. 5: Isosteric heat of adsorption

which is the monomolecular region. The magnitude of hysteresis in the un-blanched samples was higher than that of the blanched sample. According to Caurie (2007), hysteresis could be used as an indicator of stability and

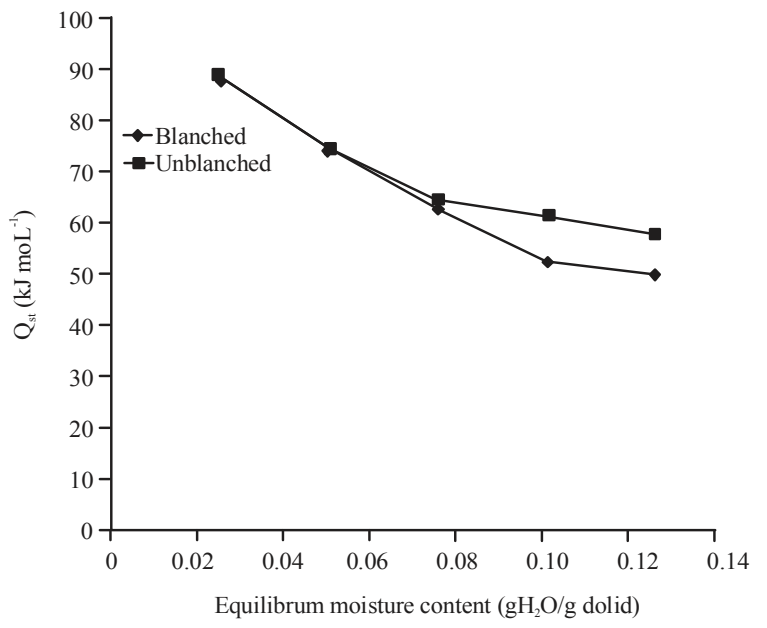

Fig. 6: Isosteric heat of desorption

quality in which increase in hysteresis reduces stability and reduction or absence of hysteresis increases food stability. Also, the magnitude of the hysteresis loop decreases as temperature increases. Similar report was reported by Oyelade et al. (2008) in their studies on white yam flour.

Modelling the sorption isotherm of water yam flour samples: The modeling results of the experimental EMC of the adsorption and desorption isotherm obtained at the three temperatures are presented in Table 2-5. The Peleg, GAB and Oswin Model gave better description of the experimental data obtained for all the samples than other models at the various sorption temperatures. Akanbi et al. (2006) reported that more than one sorption models described the sorption characteristics of tomato slides, however, GAB model was observed to give the overall best fit based on the highest $\mathrm{R}^{2}$ value and lowest SEE value obtained for the adsorption and desorption experimental data obtained.

The application of the GAB model in describing the monolayer and multilayer moisture content made its application versatile for various foods than other sorption models. The monolayer moisture content $\left(\mathrm{X}_{\mathrm{m}}\right)$ obtained for the un-blanched samples was observed to be greater than that obtained for the blanched samples during the adsorption and desorption process. This could be attributed to the loss of the starch content in the blanched samples during processing. It has been reported that foods with high starch content had higher monolayer moisture content (Kaymak-Ertekin and Gedik, 2004).

Isosteric heat of sorption: The isosteric heat of adsorption and desorption obtained for the blanched and un-blanched samples decreased with increasing moisture content as shown in Fig. 5 and 6. This indicates that at lower moisture content (initial sorption stage) high binding energy with highly active polar sites occurred on 
J. Food Technol., 17 (4): 46-52, 2019

Table 2: Parameters for the adsorption isotherm model for blanched water yam flour

\begin{tabular}{lcccccccc}
\hline Models & Temperatures $\left({ }^{\circ} \mathrm{C}\right)$ & $\mathrm{A}$ & $\mathrm{B}$ & $\mathrm{C}$ & $\mathrm{D}$ & $\mathrm{X}_{\mathrm{m}}$ & $\mathrm{R}^{2}$ & $\mathrm{SEE}$ \\
\hline Peleg & 25 & 0.216 & 5.017 & 0.216 & 5.213 & - & 0.9156 & 0.0361 \\
& 35 & 0.104 & 1.072 & 0.294 & 15.685 & - & 0.9987 & 0.0030 \\
\multirow{3}{*}{ Oswin } & 45 & 0.007 & 0.088 & 0.137 & 2.663 & - & 0.9916 & 0.0046 \\
& 25 & 0.053 & 0.620 & - & - & - & 0.9818 & 0.0168 \\
& 35 & 0.045 & 0.550 & - & - & - & 0.9977 & 0.0040 \\
Smith & 45 & 0.035 & 0.434 & - & - & - & 0.9236 & 0.0138 \\
& 25 & -0.007 & -0.105 & - & - & - & 0.9142 & 0.0364 \\
& 35 & -0.004 & -0.074 & - & - & - & 0.9714 & 0.0144 \\
Henderson & 45 & 0.001 & -0.043 & - & - & - & 0.9618 & 0.0098 \\
& 25 & 6.560 & 0.706 & - & - & - & 0.9564 & 0.0260 \\
& 35 & 10.319 & 0.832 & - & - & - & 0.9851 & 0.0104 \\
GAB & 45 & 28.863 & 1.102 & - & - & - & 0.9672 & 0.0091 \\
& 25 & 92.868 & 0.971 & - & - & 0.026 & 0.9845 & 0.0155 \\
& 35 & 11.384 & 0.942 & - & - & 0.025 & 0.9955 & 0.0057 \\
& 45 & 0.155 & 0.566 & - & - & 0.386 & 0.9874 & 0.0056 \\
\hline
\end{tabular}

Table 3: Parameters for the adsorption isotherm model for unblanched water yam flour

\begin{tabular}{|c|c|c|c|c|c|c|c|c|}
\hline Models & Temperatures $\left({ }^{\circ} \mathrm{C}\right)$ & A & $\mathrm{B}$ & $\mathrm{C}$ & $\mathrm{D}$ & $X_{m}$ & $\mathrm{R}^{2}$ & SEE \\
\hline \multirow[t]{3}{*}{ Peleg } & 25 & 0.209 & 3.547 & 0.209 & 3.547 & - & 0.8849 & 0.0456 \\
\hline & 35 & 0.777 & 38.883 & 0.141 & 1.199 & - & 0.9996 & 0.0019 \\
\hline & 45 & 0.021 & 0.454 & 0.134 & 2.886 & - & 0.9956 & 0.0035 \\
\hline \multirow[t]{3}{*}{ Oswin } & 25 & 0.070 & 0.554 & - & - & - & 0.9774 & 0.0202 \\
\hline & 35 & 0.055 & 0.507 & - & - & - & 0.9987 & 0.0073 \\
\hline & 45 & 0.040 & 0.420 & - & - & - & 0.9420 & 0.0127 \\
\hline \multirow[t]{3}{*}{ Smith } & 25 & -0.002 & -0.113 & - & - & - & 0.9349 & 0.0343 \\
\hline & 35 & 0.000 & -0.080 & - & - & - & 0.9789 & 0.0133 \\
\hline & 45 & 0.003 & -0.046 & - & - & - & 0.9724 & 0.0087 \\
\hline \multirow[t]{3}{*}{ Henderson } & 25 & 7.073 & 0.833 & - & - & - & 0.9504 & 0.0299 \\
\hline & 35 & 11.115 & 0.931 & - & - & - & 0.9822 & 0.0123 \\
\hline & 45 & 29.456 & 1.149 & - & - & - & 0.9802 & 0.0074 \\
\hline \multirow[t]{3}{*}{ GAB } & 25 & 29.157 & 0.952 & - & - & 0.035 & 0.9731 & 0.0221 \\
\hline & 35 & 9.481 & 0.923 & - & - & 0.031 & 0.9890 & 0.0096 \\
\hline & 45 & 0.171 & 0.544 & - & - & 0.424 & 0.9939 & 0.0041 \\
\hline
\end{tabular}

Table 4: Parameters for the desorption isotherm models for blanched water yam flour

\begin{tabular}{lcccccccc}
\hline Models & Temperatures $\left({ }^{\circ} \mathrm{C}\right)$ & $\mathrm{A}$ & $\mathrm{B}$ & $\mathrm{C}$ & $\mathrm{D}$ & $\mathrm{X}_{\mathrm{m}}$ & $\mathrm{R}^{2}$ & $\mathrm{SEE}$ \\
\hline Peleg & 25 & 0.186 & 2.768 & 0.186 & 2.768 & - & 0.9039 & 0.0377 \\
& 35 & 0.215 & 9.855 & 0.110 & 0.820 & - & 0.9984 \\
\multirow{4}{*}{ Oswin } & 45 & 0.008 & 0.097 & 0.133 & 2.334 & - & 0.0033 \\
& 25 & 0.083 & 0.477 & - & - & - & 0.9926 & 0.0043 \\
& 35 & 0.061 & 0.452 & - & - & - & 0.9947 & 0.0088 \\
Smith & 45 & 0.040 & 0.399 & - & - & - & 0.9256 & 0.0034 \\
& 25 & 0.010 & -0.106 & - & - & - & 0.0105 \\
& 35 & 0.007 & -0.074 & - & - & - & 0.9973 & 0.0220 \\
\multirow{3}{*}{ Henderson } & 45 & 0.005 & -0.043 & - & - & - & 0.9554 & 0.0075 \\
& 25 & 8.519 & 0.949 & - & - & - & 0.9675 \\
& 35 & 13.665 & 1.028 & - & - & - & 0.0220 \\
GAB & 45 & 32.672 & 1.173 & - & - & - & 0.9903 & 0.0083 \\
& 25 & 61.861 & 0.926 & - & - & 0.042 & 0.9925 & 0.0084 \\
& 35 & 12.590 & 0.898 & - & - & 0.035 & 0.9978 & 0.0105 \\
& 45 & 0.178 & 0.496 & - & - & 0.492 & 0.9902 & 0.0039 \\
\hline
\end{tabular}

$\mathrm{X}_{\mathrm{m}}=$ the monolayer moisture content; $\mathrm{A}-\mathrm{C}=$ the model constants; $\mathrm{R}^{2}=$ the coefficient of determination; SEE is the sum of estimates error

the food surface thereby forming a monomolecular layer. According to Oluwamukomi et al. (2008), sorption occurs on the less active sites giving rise to lower heats of sorption as the sites becomes occupied. Similar effects of moisture on the isosteric heat of sorption were also reported by Akanbi et al. (2006) for tomato, KaymakErtekin and Gedik (2004)for fruits and McMinn and Magee (2003) for potato.
The un-blanched flour samples had higher heat of absorption and desorption values than the blanched samples at the various moisture contents observed. This indicates that the un-blanched flour samples had more polar sites in which higher amounts of heat and energy of binding between the water molecules and its surface will be required. 
J. Food Technol., 17 (4): 46-52, 2019

Table 5: Parameters for the desorption isotherm models for unblanched water yam flour

\begin{tabular}{lcccccccc}
\hline Models & Temperatures $\left({ }^{\circ} \mathrm{C}\right)$ & $\mathrm{A}$ & $\mathrm{B}$ & $\mathrm{C}$ & $\mathrm{D}$ & $\mathrm{X}_{\mathrm{m}}$ & $\mathrm{R}^{2}$ & $\mathrm{SEE}$ \\
\hline Peleg & 25 & 0.191 & 1.949 & 0.191 & 1.949 & - & 0.9263 & 0.0365 \\
& 35 & 0.131 & 1.880 & 0.131 & 1.880 & - & 0.9571 & 0.0192 \\
\multirow{3}{*}{ Oswin } & 45 & 0.022 & 0.325 & 0.130 & 2.322 & - & 0.9951 & 0.0054 \\
& 25 & 0.109 & 0.417 & - & - & - & 0.9960 & 0.0085 \\
& 35 & 0.078 & 0.403 & - & - & - & 0.9921 & 0.0083 \\
Smith & 45 & 0.048 & 0.365 & - & - & - & 0.9326 & 0.0137 \\
& 25 & 0.021 & -0.118 & - & - & - & 0.9869 & 0.0154 \\
& 35 & 0.015 & -0.081 & - & - & - & 0.9926 & 0.0080 \\
\multirow{3}{*}{ Henderson } & 45 & 0.010 & -0.045 & - & - & - & 0.9481 & 0.0120 \\
& 25 & 9.895 & 1.191 & - & - & - & 0.9860 & 0.0159 \\
& 35 & 16.364 & 1.232 & - & - & - & 0.9977 & 0.0044 \\
GAB & 45 & 43.394 & 1.355 & - & - & - & 0.9771 & 0.0080 \\
& 25 & 14.687 & 0.892 & - & - & 0.063 & 0.9925 & 0.0116 \\
& 35 & 7.251 & 0.863 & - & - & 0.051 & 0.9982 & 0.0039 \\
& 45 & 0.251 & 0.441 & - & - & 0.545 & 0.9934 & 0.0043 \\
\hline
\end{tabular}

$\mathrm{X}_{\mathrm{m}}=$ the monolayer moisture content; A-C = the model constants; $\mathrm{R}^{2}=$ the coefficient of determination; SEE is the sum of estimates error

\section{CONCLUSION}

The sorption isotherm of the water yam flour exhibits hysteresis phenomenon and a sigmoidal shape of type II isotherm. The Equilibrium Moisture Content (EMC) of the flour samples decrease with increase in temperature at constant water activity for both adsorption and desorption process. The EMC of the blanched samples was lower than that of the un-blanched samples hence; the blanching treatment affects the equilibrium moisture content of the flour samples at particular relative humidity and storage conditions. The magnitude of hysteresis exhibited was also affected by the blanching treatment and the sorption temperature. The GAB Model best described the adsorption and desorption experimental data of the flour samples at the various sorption temperatures. The blanching treatment also affects the GAB mono layer moisture content of the flour samples by lowering its value. The heat of sorption decreases with increasing moisture content. Conclusively, this information predicted the stability behavior of water yam flour when placed under different storage conditions thereby enhancing its shelf life and improving its acceptability globally.

\section{REFERENCES}

Akanbi, C.T., R.S. Adeyemi and A. Ojo, 2006. Drying characteristics and sorption isotherm of tomato slices. J. Food Eng., 73: 157-163.

Al-Muhtaseb, A.H., W.A.M. Mcminn and T.R.A. Magee, 2002. Moisture sorption isotherm characteristics of food products: A review. Food Bioprod. Process., 80: 118-128.

Andrade, P.R.D., M.R. Lemu and C.C.E. Perez, 2011. Models of sorption isotherms for food: Uses and limitations. Vitae, 18: 325-334.
Babajide, J.M., S.O. Babajide and O.B. Oyewole, 2007. Survey of traditional dry-yam slices (Gbodo) processing operation in South West Nigeria. American-Eurasian J. Sustainable Agric., 1: 45-49.

Barbosa-Canovas, G.V., A.J. Fontana, S.J. Schmidt and T.P. Labuza, 2008. Water Activity Prediction and Moisture Sorption Isotherms. In: Water Activity in Foods, Labuza, T.P. and L. Altunakar (Eds.)., Blackwell Publishing, Oxford, UK., pp: 109-154.

Caurie, M., 2007. Hysteresis phenomenon in foods. Int. J. Food Sci. Technol., 42: 45-49.

Gogtus, F., M. Maskan and A. Kaya, 1998. Sorption isotherms of Turkish delight. J. Food Process. Preserv., 22: 345-357.

Goula, A.M., T.D. Karapantsios, D.S. Achilias and K.G. Adamopoulos, 2008. Water sorption isotherms and glass transition temperature of spray dried tomato pulp. J. Food Eng., 85: 73-83.

Harijono, T.E., D.S. Saputri and J. Kusnadi, 2013. Effect of blanching on properties of water yam (Dioscorea alata) flour. Adv. J. Food Sci. Technol., 5: $1342-1350$.

Kaymak-Ertekin, F. and A. Gedik, 2004. Sorption isotherms and isosteric heat of sorption for grapes, apricots, apples and potatoes. LWT-Food Sci. Technol., 37: 429-438.

McMinn, W.A.M. and T.R.A. Magee, 2003. Thermodynamic properties of moisture sorption of potato. J. Food Eng., 60: 157-165.

Mignouna, H.D. and A. Dansi, 2003. Yam (Dioscorea ssp.) domestication by the Nago and Fon ethnic groups in Benin. Genetic Resour. Crop Evol., 50: 519-528.

Mignouna, H.D., M.M. Abang and R. Asiedu, 2003. Harnessing modern biotechnology for tropical tuber crop improvement: Yam (Dioscorea spp.) molecular breeding. Afr. J. Biotechnol., 2: 478-485. 
Oluwamukomi, M.O., I.A. Adeyemi and O.O. Odeyemi, 2008. Adsorption isotherm and thermodynamic characteristics of soy-melon enriched Gari semolina from cassava. Agricultural Eng. Int. CIGR J., Vol. 10,

Opara, L.U., 1999. Yam Storage. In: CIGR Handbook of Agricultural Engineering, Bakker-Arkema et al. (Eds.). Vol. IV, Agro Processing. The American Society of Agricultural Engineers, St. Joseph, MI., pp. 182-214.

Owo, H.O., A.A. Adebowale, O.P. Sobukola, A.O. Obadina and O.E. Kajihausa et al., 2017. Adsorption isotherms and thermodynamics properties of water yam flour. Qual. Assur. Safety Crops Foods, 9: 221-227.

Oyelade, O., S. Khokhar, T. Afolabi and B. Olanipekun, 2014. Effect of heat-moisture treatment on equilibrium moisture content models for cassava starches. Food Sci. Qual. Manage., Vol. 28,
Oyelade, O.J., T.Y. Tunde-Akintunde and J.C. Igbeka, 2008. Predictive equilibrium moisture content equations for yam (Dioscorea rotundata, Poir) flour and hysteresis phenomena under practical storage conditions. J. Food Eng., 87: 229-235.

Peng, G., X. Chen, W. Wu and X. Jiang, 2007. Modeling of water sorption isotherm for corn starch. J. Food Eng., 80: 562-567.

Raj, B., A.E. Raj and K.R. Kumar, 2002. Moisture-sorption characteristics of starch/ low-density polyethylene films. J. Appl. Polym. Sci., 84: 1193-1202.

Satimehin, A.A., 2017. Kinetics of gelatinized white yam (Dioscorea rotundata, Poir) during convective drying. FUOYE J. Eng. Technol., 2: 47-52.

Tsami, E., D. Marinos-Kouris and Z.B. Maroulis, 1990. Water sorption isotherms of raisins, currants, figs, prunes and apricots. J. Food Sci., 55: 1594-1597. 